\title{
RECORDS GROUP. PROBLEM ZESPOŁOWOŚCI W ARCHIWISTYCE AMERYKAŃSKIEJ
}

\section{Słowa kluczowe}

teoria archiwalna; zespół archiwalny; record group; archiwistyka amerykańska; Archiwum Narodowe w Waszyngtonie

\section{Keywords}

archival theory; archival fonds; record group; American archival studies; National Archives in Washington

\section{Streszczenie}

Termin record group - grupa zespołów (akt) - jest pojęciem rzadko opisywanym w polskiej literaturze archiwistycznej. Najczęściej kojarzony jest z zespołem złożonym, z uwagi na skomplikowaną strukturę i zatarte granice zespołu, będące wynikiem odmiennego od polskiego systemu administracji.

Podejmowane w latach powojennych próby modyfikacji i rozszerzenia zakresu pojęcia zespołu złożonego zbliżyły go znaczeniowo do terminu record group. Irena Radkte

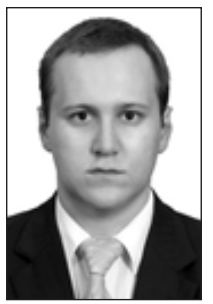

Bartosz Nowożycki ukończył studia magisterskie w zakresie historii na Uniwersytecie Warszawskim, doktoryzował się w Uniwersytecie Mikołaja Kopernika w Toruniu, w 2016 r. Obecnie pracuje w Naczelnej Dyrekcji Archiwów Państwowych w Warszawie. Kilkakrotnie przebywał na stażach naukowych w Stanach Zjednoczonych (w latach 2010 -2016). Jest autorem lub współautorem 8 książek i ponad 30 artykułów. Jego zainteresowania badawcze koncentrują się na historii współczesnej, problemach teorii i praktyki archiwalnej. E-mail: bnowozycki@gmail.com 
w referacie wygłoszonym na VI Archiwalnej Konferencji Metodycznej w Warszawie w 1970 r. zaproponowała, aby za zespół złożony uznać taki, w skład którego weszły akta obcej proweniencji, stanowiące sukcesję bierną. Bohdan Ryszewski odnosząc się do koncepcji Radkte zauważył również fakt, iż sukcesja czynna może stanowić źródło komplikacji. Takie ujęcie definicji zespołu złożonego nie odpowiadało jednak znaczeniu amerykańskiego terminu stanowiącego formę ponadzespołową.

Istoty problemu dotknął Bogdan Kroll, który zauważył, że konstrukcja archiwalna zawierająca materiały różnej proweniencji nie może być traktowana jako zespół archiwalny, ani zespół złożony. Dostrzegając rozbieżność między strukturą i podziałem zasobu archiwalnego a teorią archiwalną zaproponował odejście od stosowania terminu zespół złożony i wprowadzenie pojęcia kompleks archiwalny. Kompleks archiwalny miały stanowić materiały archiwalne różnej proweniencji połączone (poza lub w archiwum) w zespoły, lub części zespołów archiwalnych różnych instytucji, których aktotwórcy posiadali wspólną charakterystykę - funkcję. Ów kompleks miał stanowić odrębną jednostkę podziału logicznego zasobu, grupującą przy zespole tworzącym rdzeń kompleksu wszystkie zespoły i/lub części zespołów wchodzące w jego skład.

Problem braku form ponadzespołowych w polskiej teorii archiwalnej dostrzegł również Józef Siemieński formułując pojęcie zespołu wyższego rzędu. Według jego koncepcji zespół wyższego rzędu był zespołem zespołów archiwalnych wytwarzanych przez rozmaite władze i urzędy (w ramach jednego ustroju) stanowiące osobną hierarchię.

Na potrzeby niniejszego artykułu autor przyjął tłumaczenie terminu record group na język polski jako grupa zespołów (akt). Termin grupa zespołów (akt) został zdefiniowany w 1941 r. przez Solona Justusa Bucka, kierującego Archiwum Narodowym w Waszyngtonie. Pod pojęciem record group rozumiano jednostkę podziału logicznego zasobu archiwalnego ustanawianą w dowolny sposób, o rozmiarze i charakterze dogodnym do jej porządkowania, opracowania i udostępniania, z poszanowaniem zasady proweniencji.

$7 \Gamma$ ermin record group - grupa zespołów (akt) - jest rzadko opisywany w polskiej literaturze archiwistycznej. Niniejszy tekst jest próbą przybliżenia polskiemu czytelnikowi problemu zespołowości w archiwistyce amerykańskiej. Pozwoli również wyjaśnić termin stosowany przez archiwa w Stanach Zjednoczonych, który w Polsce kojarzony jest najczęściej z pojęciem zespołu złożonego z uwagi na skomplikowaną strukturę i zatarte granice zespołu. $\mathrm{Na}$ potrzeby niniejszego artykułu autor przyją tłumaczenie terminu record group na język polski jako grupa zespotów (akt).

Współczesna praktyka archiwalna w Stanach Zjednoczonych ma swoje korzenie w dorobku i doświadczeniach lat pracy Archiwum Narodowego w Waszyngtonie, dla których podstawę teoretyczną stanowiła archiwistyka europejska ${ }^{1}$.

${ }^{1}$ Z europejskiej archiwistyki zaczerpnięto zasadę proweniencji, poszanowania układu akt nadanego przez twórcę, a także przekonanie o tym, iż dokumentacja aktotwórcy 
Jednym z rezultatów działań Archiwum Narodowego było stworzenie przyjętego powszechnie pojęcia typu zespołu archiwalnego - record group.

W XIX i na początku XX w. podstawą jednostkę podziału logicznego gromadzonych materiałów archiwalnych stanowiła kolekcja, która łączyła dokumentację proweniencji publicznej i prywatnej ${ }^{2}$. Przyjęcie przez archiwistów amerykańskich terminu kolekcja wynikało z faktu, iż znaczna część materiałów archiwalnych przechowywana była w bibliotekach, gdzie stosowano właściwą dla nich metodykę opracowania i opisu rękopisu ${ }^{3}$.

Pod koniec pierwszej dekady XX w. środowisko archiwistów amerykańskich rozpoczęło dyskusję o konieczności wyzwolenia archiwistyki amerykańskiej spod wpływu bibliotek i wyodrębnienia jej jako samodzielnej dziedziny nauki ${ }^{4}$. Waldo G. Leland, archiwista, który zapoznał amerykanów z zasadą proweniencji i zachowania oryginalnego układu akt, proponował homogeniczny układ akt, oparty na seriach i grupach dokumentów, które traktował jak organiczną całość ${ }^{\text {. }}$

Idea podziału wewnętrznego zasobu archiwalnego w sposób inny niż kolekcje lub serie przeniknęła do archiwistyki amerykańskiej za pośrednictwem pracy Hilarego Jenkinsona pt. A Manual of Archives Administration wydanej w 1922 r. w Londynie ${ }^{6}$. Jenkinson wprowadził w nim termin archives group, różniący się od europejskiego fonds d'archives. Termin ten określał organiczną całość dokumentacji powstałej w wyniku działań samodzielnej jednostki administracji publicznej

stanowi organiczną całość, która posiada hierarchiczną strukturę. M. J. Evans, Authority Control: An Alternative to the Records Group Concept, „The American Archivist”, t. 49, 1986, nr 3, s. 250.

2 R. C. Berner, Archival Theory and Practice In the United States: A Historical Analysis, Seattle - Londyn 1983, s. 11 i n.

${ }^{3}$ L. J. Gilliland-Swetland, The Provenance of a Profession: The Permanence of the Public Archives and Historical Manuscripts Traditions in American Archival History, [w:] American archival studies. Readings in theory and practice, red. R. C. Jimerson, Chicago 2000, s. 123-142.

${ }^{4}$ R. J. Cox, Ch. Dollar, R. Hirsch, P. J. Wosh; Founding Brothers: Leland Buck and Cappon and the Formation of the Archives Profession, „The American Archivist” t. 74, 2011, supplement, s. 404:4-8.

${ }^{5}$ Archival Principles Selections From the Writings of Waldo Gifford Leland, oprac. T. R. Schellenberg, „National Archives Staff Information Papers” nr 20, 1955, s. 1-15.

${ }^{6}$ R. Tschan, A Comparison of Jenkinson and Schellenberg on Appraisal, ,The American Archivist" t. 65, 2002, nr 2, s. 176-179 oraz T. Eastwood, Jenkinson's Writings on Some Enduring Archival Themes, „The American Archivist”, t. 67, 2004, nr 1, s. 31-44.

${ }^{7}$ H. Jenkinson, A Manual of Archival Administration, Londyn 1966, s. 101. 
W 1940 r. przetłumaczono na język angielski tzw. podręcznik holenderski z 1898 r. - Handeliding voor het ordenen en beschrijven van archvien, który legł u podstaw późniejszej dyskusji nad metodologią archiwalną w Stanach Zjednoczonych ${ }^{8}$. Podręcznik ten zapoznał amerykańskich archiwistów z pojęciem zespołu archiwalnego (fonds d'archives), stanowiącego jednostkę podziału logicznego zasobu archiwalnego ${ }^{9}$. Zdefiniowanie zespołu archiwalnego miało dla archiwistyki amerykańskiej zasadnicze znaczenie, gdyż uświadamiało związek pomiędzy dokumentacją a funkcjami i działalnością aktotwórcy, wyrażany w postaci układu nadanego dokumentacji przez jej twórcę; jak również fakt, iż dokumentacja poszczególnych aktotwórców miała być przechowywana oddzielnie ${ }^{10}$.

W latach 40. XX w. możemy obserwować wyraźne odejście od europejskich tradycji archiwalnych, związane z koniecznością stworzenia nowej metodologii dostosowanej do warunków amerykańskich doby New deal (m.in. nagłej archiwizacji dokumentacji urzędów federalnych). Istotnym elementem tego procesu była działalność powołanej w 1940 r. w Archiwum Narodowym w Waszyngtonie komisji do spraw badania archiwalnych pomocy informacyjnych oraz udostępniania akt (Finding Mediums Committee). Potrzeba powołania komisji porządkującej podstawowe zagadnienia praktyczne wynikała z faktu, iż w przeciągu 5 lat od powstania, archiwum przejęło dokumentację, która przez około 150 lat przechowywana była przez administrację federalną ${ }^{11}$. Prace tej komisji przyczyniły się nie tylko do reorganizacji waszyngtońskiego archiwum, lecz również do całkowitej zmiany metodyki opracowania materiałów archiwalnych ${ }^{12}$. Zmiany te stopniowo dotykały również mniejszych repozytoriów dokumentów i archiwów stanowych ${ }^{13}$.

Najważniejszym dla archiwistyki amerykańskiej dokonaniem komisji było wprowadzenie nowej jednostki podziału zasobu archiwalnego. Dotychczas akta

${ }^{8}$ S. Muller, J. Feith, R. Fruin Manual for the Arrangement and Description of Archives, Chicago 2003, s. 17.

9 Tamże, s. 11.

${ }^{10}$ M. Rabe Barritt, Comming to America. Dutch Archivistiek and American Archival Practice, „Archival Issues”, t. 18, 1993, nr 1, s. 43-54; T. Thomassen, New Respect for the Old Order. The Context of the Dutch Manual, „The American Archivist”, t. 66, 2003, nr 2, s. 249-270.

11 Zob. B. Nowożycki, Instytucje archiwalne przechowujące dokumenty rząd federalnego USA do 1934 r., „Archiwista Polski”, nr 1, 2014, s. 53-58.

${ }^{12}$ R. J. Cox, Ch. Dollar, R. Hirsch, P. J. Wosh, Founding Brothers, s. 404:15; R. C. Berner, Archival Theory, s. 27 i n.

${ }^{13}$ R. C. Berner, Historical Development of Archival Theory and Practices in the United States, „The Midwestern Archivist”, t. 7, 1982, nr 2, s. 106. 
rejestrowano i katalogowano $\mathrm{w}$ ramach kolejnych akcesji, bez zachowania zasady proweniencji, gdyż nie wypracowano sposobu w jaki dokumenty powinny być grupowane ${ }^{14}$. W takcie kolejnych posiedzeń komisji w 1940 r. dyskutowano nad znanymi terminami, którymi można by określić nagromadzenie dokumentacji aktotwórcy. Szukając odpowiedniej jednostki podziału zasobu zrezygnowano wówczas ze stosowania terminu kolekcja, który uznano za niedostatecznie „naukowy”, co więcej zaczerpnięty z bibliotekoznawstwa ${ }^{15}$.

Wywodzący się z francuskiej archiwistyki termin fonds odrzucono, gdyż jego definicja była niezrozumiała dla amerykańskich archiwistów. Członkowie komisji poszukiwali takiej jednostki podziału, która opierając się na zasadzie proweniencji pozwoliła by jednocześnie na łatwe zarządzanie zasobem. Natomiast stosowane przez brytyjską archiwistykę określenie - archival group - było użyteczne wyłącznie dla określania całości dokumentacji wytworzonej przez któryś z departamentów rządu federalnego. Szukano zaś terminu właściwego dla poziomu biura w departamencie. Poziom ten dyktował ówczesny system biurokratyczny o płynnej strukturze, w której jednostki organizacyjne, biura lub agencje rządowe, były często przenoszone pomiędzy poszczególnymi departamentami. Zaczęto wówczas używać pojęcia group of records, a nawet subgroup of records dla określenia jednostki podziału logicznego zasobu. Termin grupa zespołów (akt) zastosowano do opisu zasobu Archiwum Narodowego w Waszyngtonie już w 1940 r., kiedy opublikowano przewodnik po zasobie pt. Guide to the Material in the National Archives (Waszyngton 1940) ${ }^{16}$. Do identyfikacji poszczególnych grup zespotów (akt) zastosowano system numeryczny oparty na numerach akcesji. Pierwsza partia akt od danego aktotwórcy otrzymywała numer, który był wspólny dla kolejnych dopływów. Problem dowolności w podziale zasobu, w szczególności tworzenia zbiorczych grup zespołów, starano się rozwiązać poprzez tworzenie obszernych jednostek, które w razie potrzeby można by podzielić na mniejsze ${ }^{17}$.

${ }^{14}$ Jako pomoce archiwalne służyły wówczas spisy zdawczo-odbiorcze sporządzane na etapie akcesji. Archiwum Narodowe przez pierwsze kilka lat swojego istnienia nie prowadziło prac związanych z opracowaniem, a spisy były podstawą do udostępniania materiałów archiwalnych użytkownikom. R. A. Ross, The National Archives. The Formative Years, 1934-1949, [w:] Guardian of Heritage. Essays on the History of the National Archives, Waszyngton 1985, s. 45.

${ }^{15}$ R. C. Berner, Perspective on the Record Group Concept, „Georgia Archive”, t. 4, 1976, nr 1, s. 48.

${ }^{16}$ M. D. Fenyo, The Record Group Concept: A Critique, „The American Archivist”, t. 29,1966 , nr 2, s. 230.

17 Tamże, s. 231 i n. 
Ostatecznie termin grupa zespołów (akt) został zdefiniowany w $1941 \mathrm{r}$. przez Solona Justusa Bucka, kierującego Archiwum Narodowym w Waszyngtonie, w memorandum przygotowanym w oparciu o zalecenia komisji Finding Mediums Committee ${ }^{18}$. Pod pojęciem record group rozumiano jednostkę podziału logicznego zasobu archiwalnego ustanawianą w dowolny sposób, o rozmiarze i charakterze dogodnym do jej porządkowania, opracowania i udostępniania, z poszanowaniem zasady proweniencji.

Jednakże nieprecyzyjne i niejednoznaczne ujęcie definicji terminu record group utrudniało stosowanie tego pojęcia praktyce. Grupa zespołów (akt) miała stanowić podstawową jednostkę porządkowania i opisu systematycznie wzrastającego zasobu archiwalnego. Na etapie akcesji nie zawsze możliwym było uzyskanie pełnych informacji o zawartości dokumentacji lub funkcji jej wytwórcy, dlatego opierano się na informacjach wynikających kontekstu administracyjnego dotyczących powstania i gromadzenia akt. W chwili przejęcia do zasobu waszyngtońskiego archiwum akta rejestrowano i dzielono w sposób ułatwiający ich późniejsze zarządzanie oraz umożliwiający optymalną alokacje sił i środków niezbędnych do ich opracowania i udostępnienia. Przyjęta zasada podziału gromadzonych materiałów archiwalnych na jednostki umożliwiające zarządzanie nimi była słuszna, lecz przy braku zrozumienia zasady proweniencji i myleniu informacji o twórcy z informacjami o zespole (zbiorze) prowadziła do przekonania, że akta podobnie jak ich wytwórcy są elementem hierarchii ${ }^{19}$.

Twórca hierarchicznego modelu opisu materiałów archiwalnych Oliver W. Holmes wskazując na genezę pojęcia record group stwierdził, iż brytyjski termin archives group, oznaczający całość dokumentacji jednostki organizacyjnej (nie ważne jak bardzo rozbudowanej), nie przystaje do warunków amerykańskich, w których podział ten prowadził by do tworzenia grup zespołów (akt) o rozmiarach przekraczających możliwości zarządzania nimi. Dlatego też zdecydowano się dzielić dokumentację dużych agencji federalnych - departamentów na mniejsze grupy. Stosowany w europie termin fonds uznał, podobnie jak archives group, za skrajny i nieodpowiadający warunkom amerykańskim sposób podziału materiałów archiwalnych. Według niego tworzenie zespołów dla każdej jednostki administracji federalnej było by niekorzystne z punktu widzenia zarządzania zasobem archiwalny ${ }^{20}$.

18 Seventh Annual Report of the Archivist of the United States. For the Fiscal Year Ending June 30, 1941, Waszyngton 1942, s. 29.

19 M. J. Evans, Authority Control, s. 251.

20 Zob. O. W. Holmes., Archival Arrangement - Five Different Operations at Five Differ- 
Dopiero w 1950 r. Archiwum Narodowe w Waszyngtonie w ramach serii broszur metodycznych Staff Information Circular wydało tom 15, porządkujący kwestie zawiązane z zarządzaniem zasobem na poziomie grupy zespołów (akt), w tym z tworzeniem grup, włączaniem materiałów archiwalnych do grup oraz sporządzaniem pomocy informacyjnych ${ }^{21}$. Określono w niej, iż grupa zespołów (akt) ma służyć jako podstawowe narzędzie klasyfikacji i organizacji materiałów archiwalnych danego twórcy, a także celom administracyjnym związanym z zarządzaniem nimi. Zaznaczając jednocześnie, iż obowiązująca definicja record group ma charakter ogólny i wymaga stosownych objaśnień ${ }^{22}$. Opierając się na doświadczeniach lat powojennych (1945-1950) wypracowano następujące zalecenia:

1. Każdy nowy nabytek do zasobu archiwalnego ma być przypisany wyłącznie do jednej grupy zespołów (akt). Określając granice grupy zespołów (akt) należy mieć na uwadze akta pozostające poza zasobem archiwum, jak również przyszłe dopływy do danej grupy. Dopuszczono również możliwość tworzenia grupa zespołów (akt) dla jednostek administracji federalnej, których dokumentacja nie znalazła się jeszcze w zasobie archiwum.

2. Czynnikiem, który decyduje o przydzieleniu nabytku do jednej z grup zespołów (akt), o utworzeniu z niego podgrupy w ramach istniejącej grupy, czy też rozbiciu nabytku na kilka grup, jest rozmiar. Ilość grup zespołów (akt) oraz ich rozmiary powinny ułatwiać administrowanie zasobem oraz wykonywanie podstawowych funkcji archiwum.

3. Nabytek na poziomie biura lub innej jednostki departamentu administracji federalnej (bureau level) stanowi grupę zespołów (akt), jeśli biuro stanowi odrębną administracyjnie jednostkę, samodzielnie gromadzi i ewidencjonuje dokumentację. Analogicznie mogą być traktowane materiały archiwalne jednostek administracyjnych niższego szczebla nie będące częścią departamentu, które spełniają warunki określone powyżej. Nie należy tworzyć odrębnych grup zespołów (akt) dla jednostek wchodzących w skład departamentów lub agencji federalnych, których dokumentacja przechowywana jest przez jednostkę nadrzędną.

ent Levels, [w:] Modern Archives Reader. Basic Readings on Archival Theory and Practice, red. M. F. Daniels, T. Walch, Waszyngton 1984, s. 162-180.

${ }^{21}$ The Control of Records at the Record Group Level, "Staff Information Circular”, Waszyngton 1950, nr. 15.

${ }^{22}$ Tamże, s. 2 i n. 
4. Dokumentacja jednostki administracyjnej najniższego szczebla (opisanego w pkt. 3) może stanowić odrębną grupę zespołów (akt) w drodze wyjątku, np. gdy jednostka posiada znaczną autonomię administracyjną, a wytwarzana przez nią dokumentacja jest obszerna i ma unikalny charakter, obejmuje również znaczny okres czasu.

5. Dokumentacja samodzielnej agencji federalnej sprawującej określoną funkcje publiczną, porównywalną rozmiarem i znaczeniem do tej tworzonej przez biura departamentów, powinna stanowić odrębną grupę zespołów (akt).

6. Główne grupy zespołów (akt) składają się z dokumentacji departamentów odnoszącej się do zarządzania i działalności tych jednostek, pochodzącej z kilku biur departamentu (najczęściej pionu administracyjnego).

7. Zbiorcze grupy zespołów (akt) składają się z dokumentacji dwóch lub więcej niezależnych od siebie agencji federalnych, których ze względu na podobny charakter łączone są w jedną jednostkę.

8. Dokumentacja poprzednika wraz z dokumentacją sukcesora powinna stanowić jedną grupę zespołów (akt), szczególnie w wypadku zrośnięcia się dokumentacji w stopniu utrudniającym jej wydzielenie. Czynnikami decydującymi o wydzieleniu dokumentacji powinny być: rozmiar dokumentacji i możliwość jej wydzielenia, a także relacje pomiędzy funkcjami poprzednika i sukcesora.

9. Dokumentacja zlikwidowanej jednostki, która nie ma sukcesora, tworzy odrębną grupę zespołów (akt). W przypadku, gdy jednostka pełni rolę likwidatora innej jednostki dokumentacja dotycząca tego procesu powinna stać się częścią grupy zespołów (akt) zawierającej większość dokumentacji likwidowanej jednostki.

10. Dokumentacja biur terenowych powinna znaleźć się w grupie zespołów (akt) centralnej jednostki. Dopuszcza się wydzielenie dokumentacji biura terenowego jako odrębnej grupy z uwagi na jej rozmiar.

11. Dokumentacja komisji, komitetów i zarządów lub innych jednostek powstająca w niewielkich ilościach powinna stanowić zbiorczą grupę zespołów (akt). Dokumentacja niewielkiej agencji federalnej może być włączona do grupy zespołów (akt) innej agencji, z którą miała związek.

12. Dokumentacja dotycząca przeniesienia funkcji z jednej agencji na drugą pozostaje w grupie zespołów (akt) agencji, która ją wytworzyła. Jednakże w sytuacji, gdy dokumentacja dotycząca przeniesienia funkcji publicznych zrośnięta jest z aktami sukcesora, wówczas pozostaje w jego grupie zespołów (akt). W sytuacji, w której może ona być w pełni wy- 
dzielona z akt sukcesora powinna być włączona do grupy zespołów (akt) twórcy.

13. Dokumentacja przekazana z jednej agencji do drugiej, bez przeniesienia funkcji publicznych, zrośnięta z aktami agencji, która ją otrzymała pozostaje w tej grupie zespołów (akt). Jednakże w sytuacji, gdy dokumentacja jest przechowywana oddzielnie powinna zostać wydzielona i włączona do grupy zespołów (akt) twórcy.

14. Zamknięte grupy zespołów (akt) to takie, do których nie nastąpią dopływy. Zaleca się, aby zamykać grupy zespołów (akt) w celu uniknięcia zmiany nazwy, dokonania ostatecznej selekcji archiwalnej, uporządkowania i opisania materiałów archiwalnych lub w przypadku zmian administracyjnych.

15. Tytuły nadawane grupom zespołów (akt) powinny być zwięzłe i wyróżniające. Powinny składać się z oficjalnej nazwy jednostki (która wytworzyła większość dokumentacji w grupie), poprzedzonej słowami „Akta ...” („Records of the ...”) Nie należy w nazwie grupy zespołów (akt) podawać nazw poprzedników lub podległych jednostek. Jeśli dwie agencje mają tę samą nazwę, wówczas należy dodać w tytule nazwę jednostki nadrzędnej lub inną informację pozwalającą je odróżnić. Tytuły zbiorczych grup zespołów (akt) powinny oddawać ich zawartość. Zmiany w nazewnictwie grup zespołów (akt) będą zachodziły w sytuacji, gdy zmianie ulega nazwa agencji federalnej, której dokumentacja przechowywana jest w archiwum. Zmiany nazw grup zespołów (akt) nie powinny być częste. W sytuacji, gdy agencja federalna zmienia nazwę, a zgromadzona dotychczas $\mathrm{w}$ archiwum dokumentacja tej agencji jest liczna i wystarczająco kompletna, należy wówczas zamknąć grupę zespołów (akt) tej agencji.

16. Numeracja grup zespołów (akt) nadawana jest zgodnie z kolejnością pierwszej akcesji materiałów archiwalnych danej jednostki administracyjnej do archiwum.

17. Zasada proweniencji powinna być podstawą tworzenia, identyfikacji oraz opisywania grup zespołów (akt) lub ich części. Inwentarze archiwalne mają umożliwiać identyfikację dokumentacji jednostki administracji federalnej jako grupy zespołów (akt) lub jej części²3.

Podczas tworzenia grupy zespołów (akt) powinna być przygotowywana karta rejestracyjna zawierająca następujące elementy: notatkę informacyjną

${ }^{23}$ Tamże, s. 3-9. 
dotyczącą aktotwórcy i materiałów archiwalnych, informację o nabytku (opis układu wewnętrznego, datację, rozmiar, numer akcesji, proweniencję akt), informację o dokumentacji pozostającej poza archiwum oraz o grupach zespołów (akt) związanych z daną grupą zespołów (akt). Do karty rejestracyjnej dołączone są pomoce informacyjne wytworzone dla danej grupy zespołów (akt), takie jak spis zdawczo-odbiorczy, inwentarz, indeksy i skorowidze oraz inwentarze topograficzne, a także dokumentacja dotycząca przekazania akt i informacje o ograniczeniach dostępu ${ }^{24}$.

W wydanej w 1964 r. pracy pt. The Management of Archives Theodore R. Schellenberg, jeden z najbardziej wpływowych amerykańskich archiwistów, w rozdziale poświęconym porządkowaniu materiałów archiwalnych w ramach grup zespołów (akt) posłużył się terminem archival groups. Definicja terminu była zbliżona do tej stosowanej przez Archiwum Narodowe w Waszyngtonie, niewielka różnica polegała na tym, że Schellenberg kład większy nacisk na użyteczność grupy zespołów (akt) jako jednostki służącej do porządkowania i opisywania materiałów archiwalnych oraz do publikacji inwentarzy. Grupy wydzielał na podstawie genezy organizacyjnej - proweniencji. Natomiast składające się na owe grupy serie akt odnosiły się wyłącznie do funkcji, w wyniku których powstawała dokumentacja. W celu ułatwienia administrowania zasobem archiwalnym wydzielił następujące grupy zespołów (akt):

a) tworzone $\mathrm{w}$ oparciu o zasadę proweniencji z dokumentacji jednostek administracji federalnych lub innych ciał zbiorowych ${ }^{25}$,

b) ogólne grupy zespołów (akt) dla dokumentacji odnoszącej się do rządu lub ciała zbiorowego jako całości (np. departamentu), a nie jako pojedynczej jednostki organizacyjnej ${ }^{26}$,

${ }^{24}$ Tamże, s. 10-12.

${ }^{25}$ Grupa ta odwoływała się bezpośrednio do definicji archive group wprowadzonej przez Jenkinsona, jednakże Schellenberg zauważył, iż w administracji federalnej jedynie kilka agencji posiadających pełną autonomię spełnia warunki postawione przez Jenkinsona. Dlatego też zalecał tworzenie tego typu grup dla jednostek, których dokumentacja stanowi odrębną całość łatwą do wydzielenia. Na poziomie stanowym i lokalnym miała to być dokumentacja większych urzędów (np. burmistrza lub sekretarza stanu), zaś w archiwach kościelnych dokumentacja określonych jednostek organizacyjnych (np. odpowiedzialnych za wydawnictwa czy też działalność misyjną).

${ }^{26}$ Dla administracji federalnej grupa ta miała składać się z dokumentacji centrali lub odnoszącej się ogólnie do agencji jako całości. Dla związków wyznaniowych taka grupa składała by się z dokumentacji centralnej instytucji oraz tej odnoszącej się ogólnie do związku wyznaniowego. W archiwach uniwersyteckich tego typu grupa zawierać miała dokumentację władz uczelni lub odnoszącą się ogólnie do niej. 
c) zbiorcze grupy zespołów (akt) dla dokumentacji określonych klas/typów tworzonych przez agencje federalne lub ciała zbiorowe ${ }^{27}$.

Schellenberg zalecał dzielenie dokumentacji dużej jednostki organizacyjnej na podgrupy w ramach jednej grupy zespołów (akt), np. dla wydziałów, sekcji, oddziałów i biur regionalnych itp. Szczególnie gdy agencja lub biuro przechodziły reorganizację, a wśród zgromadzonej przez nie dokumentacji znajdują się materiały zlikwidowanych komórek organizacyjnych ${ }^{28}$. W jego opinii archiwista powinien traktować każdą grupę lub podgrupę jako odrębną grupę, zgodnie z zasadą proweniencji. Pogląd ten podzielał w odniesieniu do serii akt, które tworzyły grupy i podgrupy zespołów (akt). Nie dopuszczając do wymieszania dokumentacji pomiędzy jednostkami podziału logicznego, jednocześnie zachowując nadany przez aktotwórcę układ ${ }^{29}$.

Zdaniem Schellenberga brytyjska jednostka podziału logicznego zasobu była odpowiednia wyłącznie dla dokumentacji jednostek organizacyjnych, które zakończyły działalność. Amerykańscy archiwiści mieli do czynienia z zespołami otwartymi, złożonymi z dokumentacji administracji federalnej, w której zachodziły częste zmiany organizacyjne. Natomiast zastosowanie francuskiego terminu fonds widział jedynie dla dokumentacji posiadające wspólną charakterystykę, pochodzącej z różnych jednostek organizacyjnych. Jego zdaniem amerykański układ oparty na grupie zespołów (akt), dzielonej na podgrupy, serie i podserie, lepiej oddawał organizację i funkcjonowanie administracji federalnej30.

Według Richarda Bernera, jednego z pierwszych krytyków koncepcji podziału zasobu na grupy zespołów (akt), podgrupy, serie i podserie, zasadniczym problemem była nieumiejętność rozróżnienia pomiędzy funkcją aktotwórcy, wyrażoną w procesie tworzenia i gromadzenia dokumentacji, a formą samej dokumentacji. Według niego podział na grupy zespołów (akt) powinien odnosić się do działalności, w wyniku której powstaje dokumentacja - co rozumiał przez proweniencję, nie zaś do formy - systemu kancelaryjnego. Kolejną słabością było ograniczenie definicji grupy zespołów (akt) wyłącznie do dokumentacji

27 Zbiorcze grupy zespołów (akt) Schellenberg chciał tworzyć w oparciu o luźnie pojmowaną francuską zasadę respect des fonds. Miała ona zawierać dokumentację różnych jednostek organizacyjnych posiadających wspólną charakterystykę. Celem tworzenia zbiorczych grup miało być połączenie dokumentacji otrzymywanej z różnych źródeł (np. komisji Kongresu USA, dotyczącej poszczególnych misji lub wydziałów uniwersyteckich).

${ }^{28}$ T. R. Schellenberg, The Management of Archives, Chicago 1964, s. 162 i nn.

29 Tamże, s. 95-105.

30 T. R. Schellenberg, Modern Archives Principles \& Practices, Chicago 2003, s. 181 i nn. 
publicznej i firmowej, a nie zaś do prywatnej, które nadal określano terminem kolekcja. Oddając tym samym spuścizny archiwalne w pole zainteresowań bibliotekarzy, poprzez rezygnację ze stosowania podstaw teoretycznych archiwistyki do ich opracowania ${ }^{31}$.

David A. Bearman i Richard H. Lytle badając możliwość zastosowania zasady proweniencji w zarządzaniu informacją odnieśli się do pojęcia grupy zespołów (akt), które dla wielu archiwistów było jej manifestacją. Stwierdzili, iż podział logiczny oparty na grupach zespołów (akt) doprowadził do zubożenia (wręcz „zidiocenia”) amerykańskiej teorii archiwalnej, ograniczając jednocześnie możliwość tworzenia pomocy informacyjnych opartych na zasadzie proweniencji. Jego zdaniem wynikało to $\mathrm{z}$ utożsamiania dokumentacji z umiejscowieniem aktotwórcy w monohierarchicznej strukturze, a także z podobieństwa grupy zespołów (akt) do systemu klasyfikacji bibliotecznej - sprowadzającego się do układu książek na półkach, w tym wypadku akt w magazynie. To wszystko tworzyło przekonanie o hierarchicznej strukturze dokumentacji, która w ramach grupy zespołów (akt) miała odtworzyć w magazynie strukturę organizacyjną aktotwórcy ${ }^{32}$.

W 1986 r. Max J. Evans, opracowując model systemu opisu archiwalnego opartego na stosowej w bibliotekach kontroli autorytatywnej, zwrócił uwagę na problem $\mathrm{z}$ dostępem do informacji o zasobie archiwalnym wynikającym $\mathrm{z}$ jego podziału na grupy zespołów (akt). W jego opinii inwentarz tworzony dla grupy zespołów (akt) był niedoskonały, gdyż grupa zespołów (akt) jest tworem sztucznym, a jej układ wewnętrzny jest arbitralny. Inwentarz prezentuje statyczny i czasowy obraz relacji zachodzących w grupie, która jednakowoż podlega zmianom wynikającym z dopływów akt. Rozwiązanie tego problemu widział w automatyzacji procesu opisu archiwalnego, poprzez wykorzystanie programów komputerowych pozwalających łączyć informacje o twórcy z informacjami o dokumentacji33.

Obecnie Archiwum Narodowe w Waszyngtonie definiuje grupę zespołów (akt) jako jednostkę podziału zasobu, wyodrębnioną w oparciu o zasadę proweniencji ${ }^{34}$, zawierającą materiały archiwalne jednostki federalnej wyższego

${ }^{31}$ R. Berner, Perspective on the Record Group, s. 50-52.

32 D. A. Bearman, R. H. Lytle, The Power of Principle of Provenance, „Archivaria”, nr 21, 1985-1986, s. 19 i nn.

${ }^{33}$ M. J. Evans, Authority Control, s. 255.

${ }^{34}$ Zasada proweniencji rozumiana jest jako narzędzie pozwalające wyodrębnić materiały archiwalne wytworzone i przechowywane przez pojedynczego twórcę, a także uporządkować je wedle przyjętego przez niego układu. 
szczebla, tj. biura lub agencji. Większość grup zespołów (akt) zawiera akta poprzedników danego twórcy. Dopuszcza się możliwość łączenia dokumentacji jednostek niższego szczebla lub tych, które funkcjonowały w krótkim czasie (mając związek administracyjny lub funkcjonalny) w zbiorczą grupę zespołów (akt). Każda z grup zespołów (akt) podzielona jest wewnętrznie na serie, które stanowią grupy dokumentów wytworzonych w określonym systemie kancelaryjnym lub zgrupowanych razem z innego powodu (np. funkcji, działalności, formy fizycznej itd.). Numer nadany grupie odzwierciedla kolejność akcesji do zasobu Archiwum Narodowego ${ }^{35}$.

Dla przykładu grupa zespołów (akt) nr 15 - Records of the Veterans Administration, z lat 1773-1985, została utworzona by gromadzić dokumentację dotyczącą praw i przywilejów weteranów oraz ich rodzin. Obejmuje dokumentację wytworzoną i zgromadzoną przez Department of Veterans Affairs (powołany w 1989 r.), poprzedników departamentu - biura, agencje i instytucje sprawujące tożsame funkcje, w tym Military Bounty Lands and Pension Branch, War Department (1810-1815); Pension Bureau, War Department (1815-1833); Office of Commissioner of Pensions, War Department (1833-1849); Bureau of Pensions, Department of the Interior (1849-1930); Bureau of War Risk Insurance, Treasury Department (1914-1921) Rehabilitation Division, Federal Board for Vocational Education (1918-1921); Veterans Bureau (1921); U.S. Veterans Bureau (1921-1930); National Asylum for Disabled Volunteer Soldiers of the United States (1866-1973) National Home for Disabled Volunteer Soldiers (1873-1930); Office of the Surgeon General, War Department (1862-1930) oraz Veterans Administration (1930-1989) ${ }^{36}$. Grupa ta liczy ponad 246 tys. jednostek archiwalnych, co stanowi ponad 82 tys. stóp sześciennych.

W opublikowanym w 2005 r. przez Stowarzyszenie Amerykańskich Archiwistów słowniku termin record group zdefiniowano jako: kolekcję dokumentów dzielących tę samą proweniencję, o rozmiarze dogodnym do zarządzania niąą W objaśnieniu definicji podano, iż grupa zespołów (akt) czasem posiada hierarchiczną strukturę układu dokumentacji (agencji federalnej i jednostek jej podległych), co rozumiane jest jako zgodne z zasadą proweniencji. Jednakże dopuszcza się podział dokumentacji rozbudowanej agencji federalnej na grupy

35 Zob. Record Group Concept, https://www.archives.gov/research/guide-fed-records/ index-numeric/concept.html (dostęp 20 III 2017 r.)

${ }^{36}$ Szczegółowy opis zawartości grupy zespołów (akt) nr 15 zob. https://www. archives.gov/research/guide-fed-records/groups/015.html.

${ }_{37}$ Zob. Glossary of Archival and Records Terminology, red. R. Pearce-Moses, Chicago 2005. 
zespołów (akt), traktując dokumentację wydziałów agencji jako samodzielne kolekcje, a nie serie w ramach grupy ${ }^{38}$. Natomiast podręcznik Archives, personal papers, and manuscripts: a cataloging manual far archival repositories, historical societies, and manuscript libraries, terminem record group określa grupę dokumentów powiązanych organizacyjnie, utworzoną w oparciu o zasadę proweniencji, ze szczególnym uwzględnieniem historii ustrojowej aktotwórcy, a także złożoności oraz ilości dokumentacji ${ }^{39}$. Definicja ta powiela określenie użyte w artykule opublikowanym w czasopiśmie „The American Archivst” (t. 37, nr 3, s. 428) w 1974 r. przez Franka B. Evansa, Donalda F. Harrison, Edwina A. Thompsona oraz Williama L. Rofesa pt. A Basic Glossary for Archivists, Manuscript Curators, and Records Managers, który był jedną z pierwszych prób zdefiniowania terminologii archiwistycznej w Stanach Zjednoczonych.

Na zakończenie należy przyjrzeć się funkcjonowaniu terminu grupy zespołów (akt) w archiwach australijskich i kanadyjskich. W 1966 r. australijski archiwista Peter J. Scott opublikował artykuł wykazujący słabości amerykańskiej koncepcji record group. Podział wewnętrzny zasobu archiwalnego na grupy zespołów (akt) prowadził do naruszenia podstawowych zasad archiwistyki. Arbitralność w przydzielaniu materiałów archiwalnych do poszczególnych grup zespołów (akt) naruszała zasadę proweniencji, gdyż w przypadku dziedziczenia akt w różnych grupach znajdowała się dokumentacja tej samej proweniencji. $\mathrm{Z}$ kolei podział serii dokumentacji danego twórcy pomiędzy różne grupy zespołów (akt) stał w sprzeczności z zasadą zachowania oryginalnego układu akt. Scott dostrzegał również szereg problemów praktycznych, grupa zespołów (akt) składająca się z serii ułożonych wedle przyjętej klasyfikacji miała charakter otwarty. Przyszłe dopływy w jego opinii zaburzały nadaną strukturę wewnętrzną, odsuwając w czasie ostateczne opracowanie grupy oraz stworzenie inwentarza książkowego, powodowały również problemy techniczne związane z przechowywaniem akt ${ }^{40}$.

Scott skrytykował również przyjętą w 1954 r. przez australijskich archiwistów definicję record group, inspirowaną H. Jenknisonem. Definiowała ona powyższe pojęcie jako wszystkie materiały archiwalne departamentu lub biura stanowiącego samodzielną jednostkę, funkcjonującego niezależnie od organów

${ }^{38}$ Zob. Record group, http://www2.archivists.org/glossary/terms/r/record-group (dostęp 20 III 2017 r.)

${ }_{39}$ Archives, personal papers, and manuscripts: a cataloging manual far archival repositories, historical societies, and manuscript libraries, oprac. S. L. Hensen, Chicago 1989, s. 9.

40 P. J. Scott, The Record Group Concept: A Case for Abandonment, „The American Archivist", t. 29, 1966, nr 4, s. 493-497. 
zewnętrznych. Według niego określenie wszystkie materiały archiwalne (all archives) było nieprecyzyjne, gdyż nie wprowadzało rozgraniczenia między dokumentacją wytworzoną a zgromadzoną przez aktotwórcę. Jako rozwiązanie problemu Scott proponował rezygnację z podziału zasobu logicznego i fizycznego na grupy zespołów (akt) i wprowadzenie systemu opartego na seriach. Serie te miały stanowić podstawowy poziom klasyfikacji zasobu. Taki podział wynikał ze sposobu zarządzania dokumentacją w australijskiej administracji. Aktotwórcy przekazywali do archiwum kompletne serie dokumentacji (o określonym układzie wewnętrznym), które były poddawane selekcji archiwalnej, opracowywane i udostępniane jako fizyczna i logiczna całość. Związki z innymi seriami lub zespołami miały być odnotowywane w inwentarzu, tak aby oddać proweniencję i kontekst powstania dokumentacji ${ }^{41}$.

W archiwistyce kanadyjskiej termin record group odnosi się wyłącznie do dokumentacji rządu federalnego. Został on zaadaptowany ze względów czysto praktycznych. Jest definiowany jako nagromadzenie dokumentacji rządu federalnego lub jego poprzednika, zachowującej ciągłość administracyjną lub organizacyjną. Oznacza to, że do record group klasyfikowane są materiały archiwalne poszczególnych departamentów, biur lub agencji, które były przechowywane odrębnie i prowadzone w oddzielnym systemie kancelaryjnym, tworząc w ten sposób zamkniętą całość. Zmiany organizacyjne w administracji federalnej i związane z nimi sukcesje dokumentacji podważały w opinii niektórych archiwistów zasadność stosowania tej jednostki podziału. Problemem było przypisanie do odpowiednich grup serii akt o rożnej proweniencji (zawierające akta więcej niż jednego wytwórcy), oparte na arbitralnej decyzji archiwisty. Decyzje, podejmowane ad hoc, dotyczące przydziału dokumentacji do odpowiednich grup zespołów (akt) powodowały pozbawienie jej kontekstu administracyjnego i zaburzenie układu nadanego przez twórcę. Calvin Vincent zalecał bardziej szczegółowy podział grup zespołów (akt) na części, tak aby nie dopuszczać do sytuacji, w której grupa składa się z kilkuset serii. Co poprawiło by tym jakość i głębię przygotowywanych dla grup zespołów (akt) pomocy informacyjnych. Pomimo wad wynikających z niedostosowania koncepcji grupy zespołów (akt) do systemu administracyjnego (szczególnie kwestii reorganizacji i dziedziczenia akt) uznał on ten sposób podziału zasobu za najbardziej efektywny dla dokumentacji publicznej. Argumentując to faktem, iż ten system podziału został ustanowiony i funkcjonuje dobrze, pomimo wspomnianych słabości. Odno-

\footnotetext{
${ }^{41}$ Tamże, s. 497-502.
} 
sząc się do koncepcji Scotta uznał, iż podział zasobu na serie akt i ich dowolne łączenie z grupami zespołów (akt) narusza podstaw teoretyczne archiwistyki ${ }^{42}$.

Terry Cook w artykule poświęconym zagadnieniu zespołu archiwalnego stwierdził, iż w praktyce amerykańskiej grupa zespołów (akt) zatraciła swój pierwotny charakter (oparty na zasadzie proweniencji), stając się sztucznym i arbitralnym tworem. W jego opinii grupa zespołów (akt), z uwagi na praktyczne i teoretyczne problemy wynikające z uznania jej za podstawową jednostkę podziału materiałów archiwalnych, nie jest obecnie bliskim odpowiednikiem zespołu archiwalnego (fond). Termin record group ma ograniczone zastosowanie, wyłącznie do dokumentacji powstającej i gromadzonej w urzędach federalnych. Sugerował by w kanadyjskiej praktyce zastosować jednostkę podziału logicznego opartą na zespole archiwalnym (dzielonym na serie, jednostki i dokumenty), który może być z powodzeniem stosowany do materiałów publicznych oraz prywatnych ${ }^{43}$.

Termin record group jest jednostką podziału funkcjonalnego zasobu archiwalnego nie zaś wynikającą z podstaw teoretycznych archiwistyki, gdyż może ją stanowić zarówno zespół prosty jak i złożony, grupa zespołów, czy też seria. Co więcej, ten typ podziału zasobu opiera się raczej na kryterium łatwości jego opracowania, przechowywania oraz udostępniania, niźli na zasadzie proweniencji. Z uwagi na fakt, iż ukształtował się on w odmiennym od polskiego systemie prawnym i w innej tradycji służby archiwalnej nie ma on odpowiednika polskiego, tym bardziej nie powinien być tłumaczony jako zespół złożony. Dlatego też zamiast poszukiwać analogicznych terminów do tych właściwych dla rodzimej archiwistyki, autor proponuje wprowadzenie nowego określenia - grupa zespołów (akt), które jego zdaniem oddaje znaczenie i charakter record group.

\section{Literatura}

Archival Principles Selections From the Writings of Waldo Gifford Leland, oprac. T. R. Schellenberg, „National Archives Staff Information Papers”, nr 20, 1955.

Archives, personal papers, and manuscripts: a cataloging manual far archival repositories, historical societies, and manuscript libraries, oprac. S. L. Hensen, Chicago 1989.

Bearman D. A., Lytle R. H., The Power of Principle of Provenance, „Archivaria”, nr 21, 1985-1986.

42 C. Vincent, A case study. The Records Group: A Concept in Evolution, „Archivaria”, nr 3, 1976/1977, s. 4-10.

43 T. Cook, The Concept of the Archival Fonds In the Post-Custodial Era: Theory, Problems and Solutions, "Archivaria”, nr 35, 1993, s. 24-28. 
Berner R. C., Archival Theory and Practice In the United States: A Historical Analysis, Seattle-Londyn 1983.

Berner R. C., Perspective on the Record Group Concept, „Georgia Archive”, t. 4, 1976, nr 1.

Cook T., The Concept of the Archival Fonds In the Post-Custodial Era: Theory, Problems and Solutions, ,Archivaria”, nr 35, 1993.

Cox R. J., Dollar Ch., Hirsch R., Wosh P. J., Founding Brothers: Leland Buck and Cappon and the Formation of the Archives Profession, „The American Archivist”, t. 74, 2011, supplement.

Eastwood T., Jenkinson's Writings on Some Enduring Archival Themes, „The American Archivist", t. 67, 2004, nr 1.

Evans M. J., Authority Control: An Alternative to the Records Group Concept, „The American Archivist", t. 49, 1986, nr 3.

Fenyo M. D., The Record Group Concept: A Critique, „The American Archivist”, t. 29, 1966, nr 2.

Glossary of Archival and Records Terminology, red. R. Pearce-Moses, Chicago 2005

Gilliland-Swetland L. J., The Provenance of a Profession: The Permanence of the Public Archives and Historical Manuscripts Traditions in American Archival History, [w:] American archival studies. Readings in theory and practice, red. R. C. Jimerson, Chicago 2000.

Holmes O. W., Archival Arrangement - Five Different Operations at Five Different Levels, [w:] Modern Archives Reader. Basic Readings on Archival Theory and Practice, red. M. F. Daniels, T. Walch, Waszyngton 1984.

Jenkinson H., A Manual of Archival Administration, Londyn 1966.

Muller S., Feith J., Fruin R., Manual for the Arrangement and Description of Archives, Chicago 2003.

Nowożycki B., Instytucje archiwalne przechowujące dokumenty rząd federalnego USA do 1934 r., „Archiwista Polski”, nr 1, 2014.

Rabe Barritt M., Comming to America. Dutch Archivistiek and American Archival Practice, „Archival Issues”, t. 18, 1993, nr 1.

Record group, http://www2.archivists.org/glossary/terms/r/record-group (dostęp 20 III 2017 r.)

Record Group Concept, https://www.archives.gov/research/guide-fed-records/index-numeric/concept.html (dostęp 20 III 2017 r.)

Ross R. A., The National Archives. The Formative Years, 1934-1949, [w:] Guardian of Heritage. Essays on the History of the National Archives, Waszyngton 1985.

Schellenberg T. R., Modern Archives Principles \& Practices, Chicago 2003

Schellenberg T. R., The Management of Archives, Chicago 1964

Scott P. J., The Record Group Concept: A Case for Abandonment, „The American Archivist”, t. 29, 1966, nr 4.

Seventh Annual Report of the Archivist of the United States. For the Fiscal Year Ending June 30, 1941, Waszyngton 1942.

The Control of Records at the Record Group Level, „Staff Information Circular”, Waszyngton 1950, nr 15. 
Thomassen T., New Respect for the Old Order. The Context of the Dutch Manual, „The American Archivist", t. 66, 2003, nr 2.

Tschan R., A Comparison of Jenkinson and Schellenberg on Appraisal, „The American Archivist", t. 65, 2002, nr 2.

Vincent C., A case study. The Records Group: A Concept in Evolution, „Archivaria”, nr 3, 1976/1977.

\section{Summary}

\section{Records Group. The problem of fonds in the American archival studies}

The term record group means a group of fonds (records) and it is a type of archival fonds rarely described in Polish archival literature. Most often it is associated with the complex archival fonds, due to its comlicated structure and blurred borderlines - an effect of administrative system varying from the Polish one.

The post-war attempts to modify and broaden the meaning of the complex fonds caused its resemblance to the term record group. Irena Radtke in her paper given during the 6th Archival Methods Conference in Warsaw in 1970 proposed, that the complex fonds should be one comprising records of foreign provenance that are an effect of passive succession. Bohdan Ryszewski, addressing Radtke's idea, noticed that passive succession might be a source of complications. However, this conceptualization of the definition of the complex fonds did not correspond with the American understanding of it as an above-fonds structure.

Bogdan Kroll has touched the core of the problem; he noticed that an archival construction comprising materials of various provenances cannot be seen neither as an archival fonds, nor as a complex fonds. He saw a discrepancy between the structure and partition of archival holdings and archival theory; thus Kroll proposed abandoning the term complex fonds and implementation of the term archival complex. The archival complex was supposed to be archival materials of various origins merged (in or outside of an archive) into fonds, or parts of archival fonds of different institutions having the same characteristic - function. The complex was supposed to make up a separate entity in logic structure of archival holdings, comprising of all archival fonds and/or their pieces being parts of the main fonds of the complex.

The problem of lack of above-fonds forms in the Polish archival theory has been also noticed by Józef Siemieński, who has formulated the term of higher-order fonds. According to his idea the higher-order fonds was a fonds of archival fonds created by various authorities and agencies (in one system) that constituted separate hierarchy.

In this article the Author used translation of the term record group into Polish grupa zespołów (akt). The term was defined in 1941 by Solon Justus Buck, in charge of the National Archives in Washington. The term record group was understood as a unit of logical division of archival holdings, set up in arbitrary way, which size and character was convenient for its processing and providing access to, while respecting the principle of provenance. 